\title{
CONCEPT OF IN-OIL PROJECT BASED ON BIOCONVERSION OF BY-PRODUCTS FROM FOOD PROCESSING INDUSTRY
}

\author{
Wojciech Czekała ${ }^{1}$ \\ 1 Institute of Biosystems Engineering, Poznan University of Life Sciences, Wojska Polskiego 28, 60-637 Poznan, \\ Poland, e-mail: wojciech@up.poznan.pl
}

Received: 2017.05.15

Accepted: 2017.08.01

Published: 2017.09.01

\begin{abstract}
More than $30 \%$ of the world's food production is wasted. Organic waste and residues are produced in a variety of sectors, including agriculture, food industry and forestry. Residues and waste are generated throughout the entire food production and use cycle: surplus food production, processing and distribution, and consumption. Some food that has not been consumed should be managed. Bioconversion using insects provides the opportunity to produce feed and energy using by-products of the agro-food industry. The aim of the work was to present the concept of "IN OIL: an innovative method for the bioconversion of by-products from food processing industry" under the project LIDER VII (co-financed by the National Centre for Research and Development). Project IN OIL is being implemented at the Poznań University of Life Sciences. INOIL's main assumption is combining two ideas - waste into energy and waste into feed. The developed method will reduce the adverse impact of unused food on the environment by using ReFood products in insect feeding (Hermetia illucens). H. illucens (Black Soldier Fly) is a Diptera characterized by a very high index of growth, and rich source of fats and proteins. The main assumption of the project is based on the introduction of by-products from the food processing industry to feeding with larvae of $H$. illucens. Biomass of insect larvae will then be processed into products that will be used for feed and energy purposes.
\end{abstract}

Keywords: food waste, refood, Hermetia Illucens, biogas production

\section{INTRODUCTION}

According to the Food and Agriculture Organization of the United Nations, FAO, more than $30 \%$ of the world's food production is unused. Despite the problem of hunger, the world wastes about 1.3 billion tons of food per year [FAO 2013]. Substantial amounts of unused food are products of plant origin [Czekała et al. 2016a, Smurzyńska et al. 2016].

Unused food must be managed legally [Czekała et al. 2014]. The most commonly practiced solution is its costly transfer to waste disposal companies. Therefore, it is necessary to look for and implement alternatives. The idea is that waste is not a source of cost but profit [FAO
2014]. This can be achieved by, for example, recycling waste or recover process [Czekała et al. 2014]. One of the directions of the above processes seems to be the use in the agricultural biogas plant, which ensures the process of biological waste disposal. Bioconversion technology using Hermetia illucens insect provides the opportunity to produce feed and energy, while allowing the plant to produce by-products of the agro-food industry [Rehman et al. 2017].

The aim of the work was to present the concept of "IN OIL: an innovative method for the bioconversion of by-products from food processing industry" under the project LIDER VII. In addition, issues related to the emergence and development of plant-based food waste have been presented. 


\section{BY-PRODUCTS FROM FOOD PROCESSING INDUSTRY}

Organic waste and residues are produced in a variety of sectors, including agriculture, food industry and forestry. However, the raw materials of vegetable origin are a diverse group [Alzate $\mathrm{T}$ et al. 2017]. They include among others: cereals, vegetables, fruits, or root crops. As mentioned earlier, according to FAO data and research, more than $30 \%$ of the world's food is wasted. Interestingly, this problem pertains to practically every country, although the rich and developed states are predominantly dominant. In these countries, the problem is the result of overproduction of food and over-buying. In turn, food is better utilized in poor and developing countries. The resulting food waste is mainly due to the lack of food storage infrastructure.

Residues and waste are generated throughout the entire food production and use cycle, including surplus food production, processing and distribution, and consumption. [Li et al. 2016].

It should be emphasized that the products that are often withdrawn from the sale still have full value. However, they are often removed from sale due to small organoleptic changes, such as malfunction or damage to the package. Another reason is, for example, withdrawal of a portion of a product after the promotional offer has expired or when the end of its useful life is approaching. [Brancoli et al. 2017].
Some food that has not been consumed should be managed [Garcia-Garcia et al. 2017]. This applies, for example, to agricultural crops that are biodegradable, i.e. degradable under the influence of microorganisms. It is therefore imperative that they are properly managed to prevent, for example, their rotting or the emission of harmful compounds into the atmosphere. Selection of substrate recovery methods should be based on their physical and chemical properties. Their functional and organoleptic characteristics should also be taken into consideration.

Using by-products from the food processing industry to produce insects and then feed and energy seems to be a rational solution. This will not only avoid waste disposal fees but also generate revenue from the sale of energy, feed or fertilizer [Ciesielczuk et al. 2017]. Especially when the waste management of plant origin does not create legal problems compared to overdue mixed food.

\section{IN-OIL PROJECT CONCEPCION}

Project IN OIL: An innovative method for the bioconversion of by-products from the food processing industry is being implemented at the Poznań University of Life Sciences. It is performed by academics, PhD students and students of three faculties: Faculty of Agronomy and Bioengineering, Faculty of Veterinary Medicine and Animal Science and Faculty of Food Science and Nutrition.

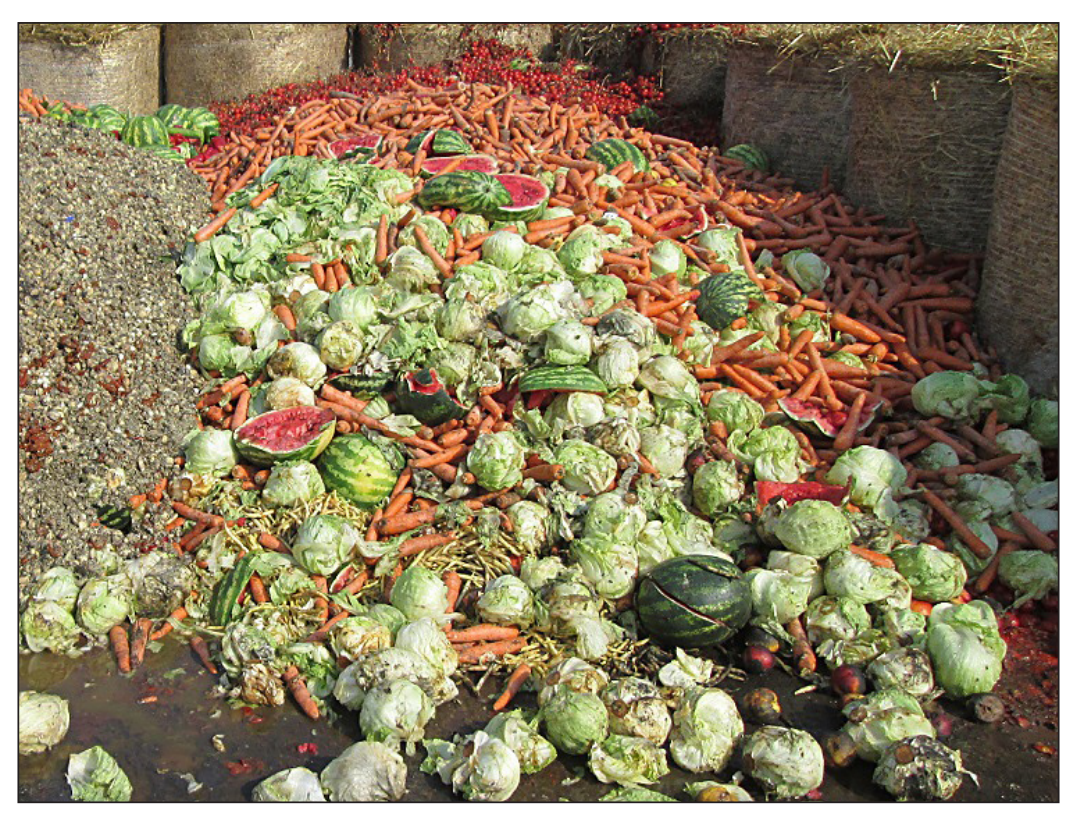

Fig. 1. Waste of vegetable origin withdrawn from sale (Wojciech Czekała) 
IN-OIL's main assumption is combining two ideas - waste into energy and waste into feed. The IN-OIL project will result in innovative bioconversion technology for the by-products of the food industry. The developed method will reduce the adverse impact of unused food on the environment by using ReFood products in insect feeding (H. illucens). Designed technology assumes processes occurring during its use are waste-free.

Rational management of agricultural products and by-products of the food industry is one of the greatest challenges of the $21^{\text {st }}$ century. However, losses related to irrational food management amount to around 89 million tons per year in the EU, of which 9 million tons per year fall to Poland. Poland is characterized by well-developed agriculture and the agro-food industry that produces biomass and waste management is one of the most important environmental protection issues. [Czekała et al. 2016b, Lucifero et al. 2016].

In general, produced waste can be divided into industrial and communal, with the mass of man-made waste much smaller than in industry. In 2015 in Poland a total of 137710 thousand tons, of which only 12226 thousand ton were municipal [GUS 2016]. However, it is the municipal waste that needs more attention because it is heavily differentiated and selective harvesting usually takes place only for part of it. Among the municipal waste, the largest potential for recycling if provided by biodegradable and high organic matter [Nabavi-Pelesaraei 2017]. This can be used, among others, to produce fertilizers, feeds or energy. However bearing in mind, that these wastes are degraded both in aerobic and anaerobic conditions, they must be collected selectively or separately as soon as possible and then anaerobically treated.

Invertebrates are the largest group of animals. The number of insect species occurring in nature is estimated at 5 to 10 million. Such a large number of species is primarily associated with being able to adapt even in difficult environmental conditions. There are about 30,000 species of insects in Poland, with the dominance of rows of beetles, flies, hymenopter and butterflies. On the other hand, the insect market in the EU is characterized by a rapid growth rate, which is currently determined by several large companies operating there. However, it is important, that the waste produced there is mainly used as food in pet food [Salemdeeb et al., 2017].
According to various assessments, more than 2 billion people in the world (mainly Africa and Asia) consume insects, which are a rich source of fats and proteins [Menozzi et al. 2017]. Even so, in developed countries, their consumption is not a popular phenomenon today. However, bearing in mind the high fertility and plumage of insects, it is possible to use them for alternative purposes [Kostecka et al. 2017]. According to preliminary data from the study, it appears that the by-products of the food industry are a wholesome, environmentally-friendly insect feed ingredient.

Hermetia illucens (Black Soldier Fly) is a Diptera originally inhabiting areas of the Americas. This species is characterized by a very high index of growth, up to several hundred $\mathrm{kg}$ in $1 \mathrm{~m}^{2}$ in one production cycle. It is currently possible to use insect fat in poultry feed, especially since its insect content in dry biomass may exceed 55\%. Bearing this in mind, the project plans a cycle of balance and growth experiments in poultry with chickens for fattening and for turkeys for fattening.

The main assumption of the project is based on the introduction of by-products from the food processing industry to feeding with larvae of $H$. illucens. Biomass of insect larvae will then be processed into products that will be used for feed and energy purposes. It is important to mention that insect fat is a healthy and safe food ingredient, and such production will be more environmentally friendly than, for example, the production of palm oil.

The aim of the project is to develop innovative bioconversion technology for food by-products using $H$. illucens larvae to produce feed fats. In addition, products produced during fat extraction, i.e. protein and chitin H. illucens, will also be used for agricultural biogas production. The production of gaseous biofuels from protein and chitin as a substrate, which cannot be used in animal nutrition, is an innovative value of the project.

An important task in the project is also to determine the use of individual food waste groups for direct biogas production. Methane fermentation is widely used because of the wide range of substrates, including food waste [Voelklein et al. 2017, Fisgativa et al. 2016]. In Poland there are about 100 agricultural biogas plants, but this number is steadily increasing [Cieślik et al. 2016]. This is due to changes supporting sources of stable energy production, i.e. those processing biomass [Gizińska-Górna et al. 2016]. Profit is also the digestion residue resulting from the an- 


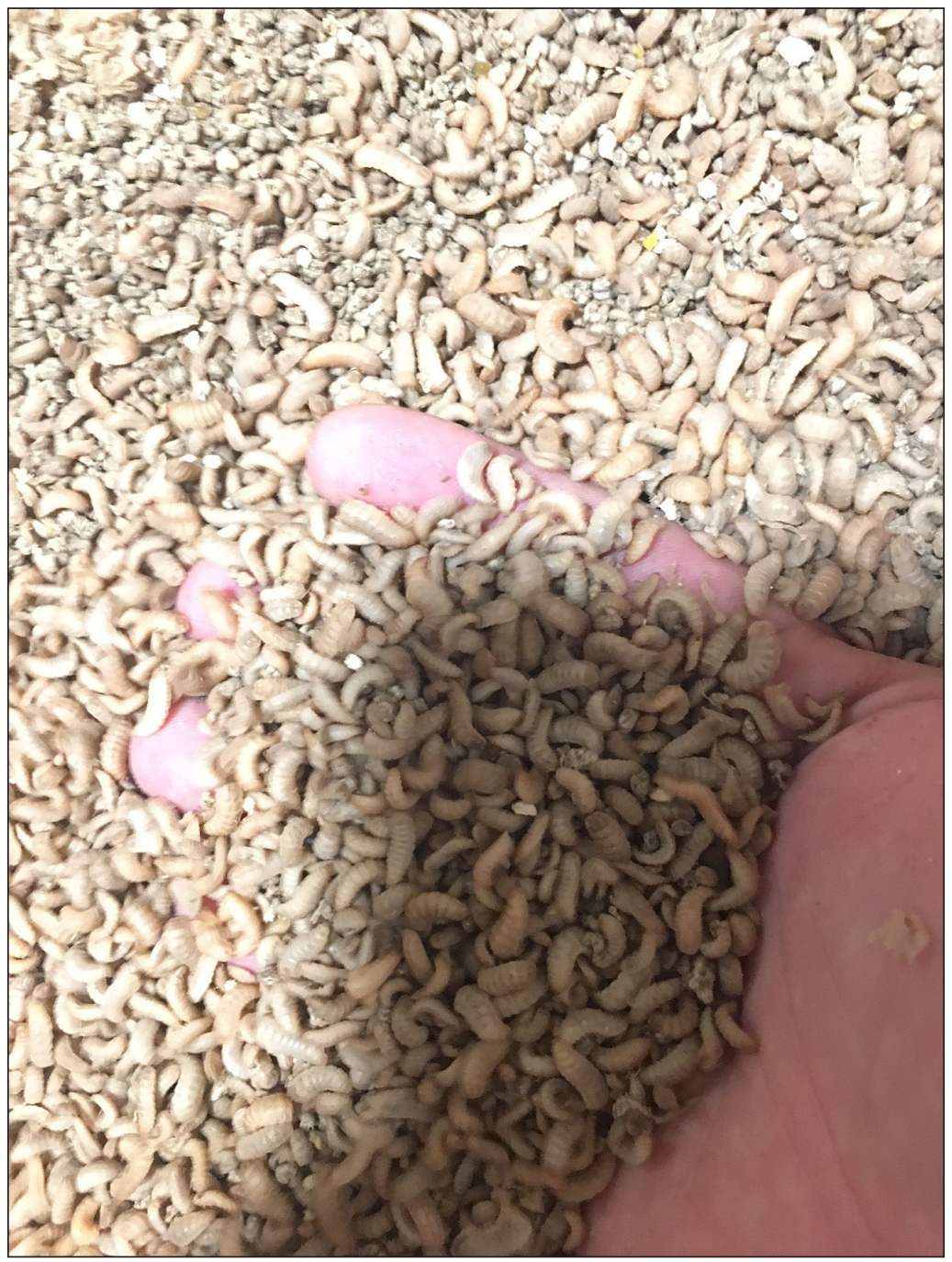

Fig. 2. Hermetia Illucens (Damian Józefiak)

aerobic digestion [Czekała et al. 2015, Czekała et al. 2012]. It is assumed that it can be sold as a valuable fertilizer or used for fertilizer purposes [Chodkowska-Miszczuk and Szymańska 2013]. This will allow to close the circulation of nutrients and give valuable nutrients for the new plant biomass.

\section{CONCLUSION}

The current trends clearly indicate that insects are becoming increasingly popular in scientific and industrial research. The main direction of research now is their use for food and feed purposes. This is due to the high content of protein and fats of good quality. Another advantage is the fact that insect production requires a small amount of water, and food can come from the products from food processing industry. There are dynamic changes in EU legislation pertaining to the use of insect biomass in human and farm animals. In the near future, insect meal is likely to be allowed in fish or poultry feed. It is assumed that the results of the project will be able to be benefited by agrofood companies, agricultural biogas plants, feed and insect producers. It is therefore necessary to conduct research on the alternative use of insect biomass and its fractions, and any actions should be safe for humans and animals.

\section{Acknowledgements}

This study was performed in the frame of the IN OIL project: An innovative method for bioconversion of by-products from food processing industry that was financed by the National Centre for Research and Development within the Lider VII Programme No. 0148/L-7/2015. 


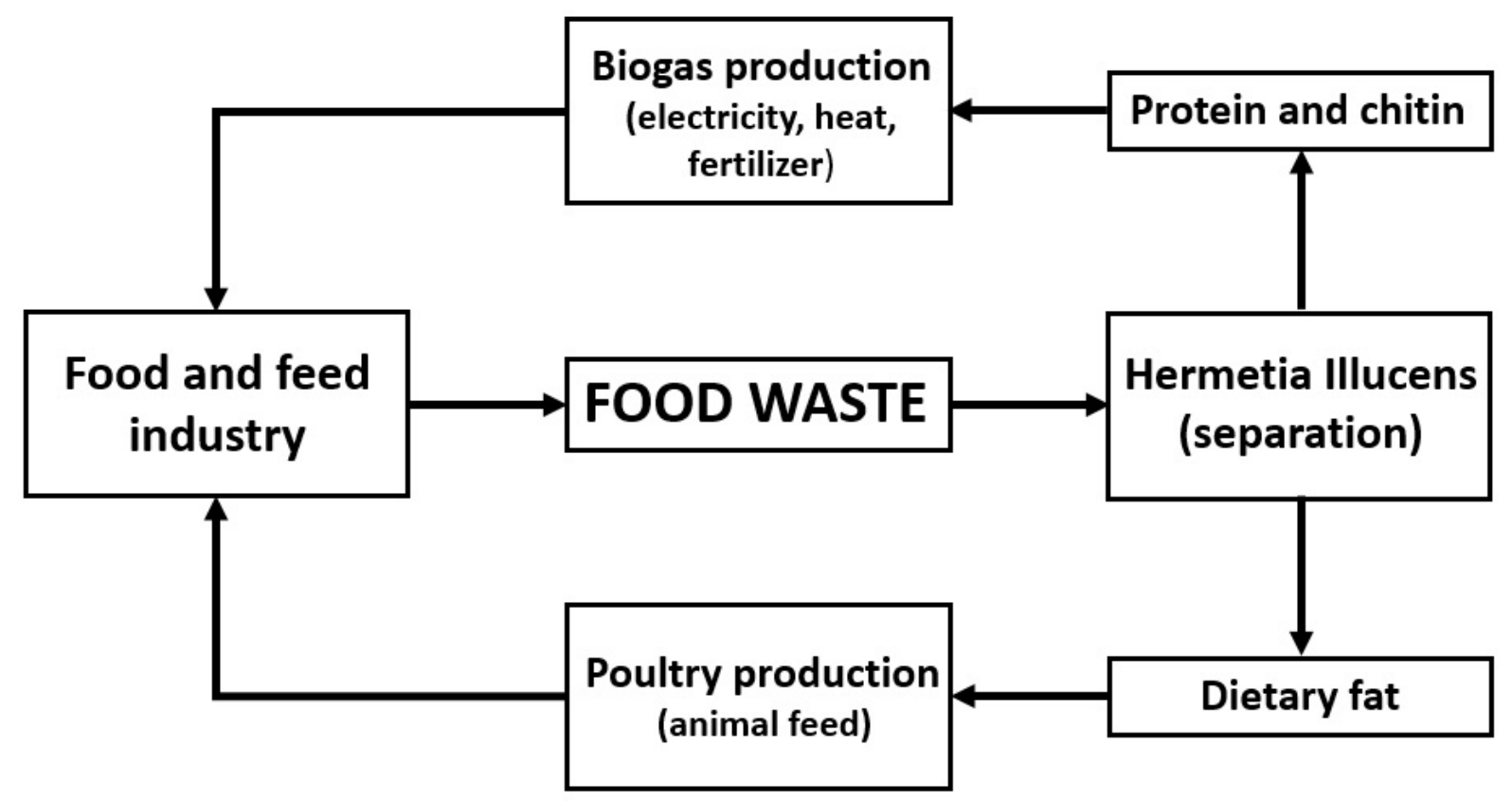

Fig. 3. Scheme of the project

\section{REFERENCES}

1. Alzate T L.M., González D., Hincapié S., Cardona S B.L., Londoño-Londoño J., Jiménez-Cartagena C. 2017. The profile of bioactive substances in ten vegetable and fruit by-products from a food supply chain in Colombia. Sustainable Production and Consumption 9, 37-43.

2. Brancoli P., Rousta K., Bolton K. 2017. Life cycle assessment of supermarket food waste. Resources, Conservation and Recycling 118, 39-46.

3. Chodkowska-Miszczuk J., Szymańska D. 2013. Agricultural biogas plants - A chance for diversification of agriculture in Poland. Renewable and Sustainable Energy Reviews 20, 514-518.

4. Ciesielczuk T., Poluszyńska J., Rosik-Dulewska C. 2017. Homemade slow-action fertilizers, as an economic solution for organic food production. Journal of Ecological Engineering 18(2), 78-85.

5. Cieślik M., Dach J., Lewicki A., Smurzyńska A., Janczak D., Pawlicka-Kaczorowska J., Boniecki P., Cyplik P., Czekała W., Jóżwiakowski K. 2016. Methane fermentation of the maize straw silage under meso- and thermophilic conditions. Energy 115(2), 1495-1502.

6. Cohen B. 2017. Modelling approaches for greenhouse gas emissions projections from the waste sector. Sustainable Production and Consumption 10, 15-20.

7. Czekała W., Pilarski K., Dach J., Janczak D., Szymańska M. 2012. Analysis of management possibilities for digestate from biogas plant (in Polish). Technika Rolnicza Ogrodnicza Leśna 4, 13-15.
8. Czekała W. Lewicki A., Janczak D. 2014. Problems concerning organic waste classification (in Polish). Przegląd Prawa Ochrony Środowiska 3, 117-128.

9. Czekała W., Dach, J., Czekała J. 2015. Operational possibilities of a biogas plant at the brewery under polish conditions. Proceedings of the 2nd International Conference on Energy \& Environment: Bringing Together Engineering and Economics, 520-525.

10. Czekała W., Smurzyńska A., Cieślik M., Boniecki P., Kozłowski K. 2016a. Biogas efficiency of selected fresh fruit covered by the Russian embargo. Energy And Clean Technologies Conference Proceedings SGEM 2016, VOLIII, 227-233.

11. Czekała W., Malińska K., Cáceres R., Janczak D., Dach J., Lewicki A. 2016b. Co-composting of poultry manure mixtures amended with biochar The effect of biochar on temperature and C-CO2 emission. Bioresource Technology 200, 921-927.

12. Fisgativa H., Tremier A., Dabert P. 2016. Characterizing the variability of food waste quality: A need for efficient valorisation through anaerobic digestion. Waste Management 50, 264-274.

13. Food and Agriculture Organization of the United Nations. 2013. Food wastage footprint Impacts on natural resources - summary report. ISBN 978-92-5-107752-8.

14. Food and Agriculture Organization of the United Nations. 2014. Mitigation of food wastage - Social costs and benefits. ISBN 978-92-5-108511-0.

15. Garcia-Garcia G., Woolley E., Rahimifard S. Optimising Industrial Food Waste Management. Procedia Manufacturing 8, 432-439. 
16. Gizińska-Górna M., Czekała W., Jóźwiakowski K., Lewicki A., Dach J., Marzec M., Pytka A., Janczak D., Kowalczyk-Juśko A., Listosz A. 2016. The possibility of using plants from hybrid constructed wetland wastewater treatment plants for energy purposes. Ecological Engineering 95, 534-541.

17. Kostecka J., Konieczna K., Cunha L.M. 2017. Evaluation of insect-based food acceptance by representatives of polish consumers in the context of natural resources processing retardation. Journal of Ecological Engineering 18(2), 166-174.

18. Nabavi-Pelesaraei A., Bayat R., HosseinzadehBandbafha H., Afrasyabi H., Berrada A. 2017. Prognostication of energy use and environmental impacts for recycle system of municipal solid waste management. Journal of Cleaner Production, 154, 602-613.

19. Li Y., Jin Y., Li J. 2016. Enhanced split-phase resource utilization of kitchen waste by thermal pretreatment. Energy 98, 155-167.

20. Lucifero N. 2016. Food Loss and Waste in the EU Law between sustainability of well-being and the implications on food system and on environment. Agriculture and Agricultural Science Proc. 8, 282-289.

21. Menozzi D., Sogari G., Veneziani M., Simoni E.,
Mora C. 2017. Eating novel foods: An application of the Theory of Planned Behaviour to predict the consumption of an insect-based product. Food Quality and Preference, 59, 27-34.

22. Rehman K., Rehman A., Cai M., Zheng L., Xiao X., Somroo A.A., Wang H., Li W., Yu Z., Zhang J. 2017. Conversion of mixtures of dairy manure and soybean curd residue by black soldier fly larvae (Hermetia illucens L.). Journal of Cleaner Production 154, 366-373.

23. Salemdeeb R., zu Ermgassen E.K.H.J., Kim M.H., Balmford A., Al-Tabbaa A. 2017. Environmental and health impacts of using food waste as animal feed: a comparative analysis of food waste management options. Journal of Cleaner Production 140(2), 871-880.

24. Smurzyńska A., Czekała W., Lewicki A., Cieślik M., Kozłowski K., Janczak D. 2016. The biogas output of vegetables utilized in the polish market due to the introduction of the Russian embargo (in Polish). Technika Rolnicza Ogrodnicza Leśna 6, 24-27.

25. Voelklein M.A., Shea R.O., Jacob A., Murphy J.D. 2017. Role of trace elements in single and twostage digestion of food waste at high organic loading rates. Energy 121,185-192.

Pracę dofinansowano ze środków Wojewódzkiego Funduszu Ochrony Środowiska i Gospodarki Wodnej w Lublinie. 